\title{
COMPARATIVE CHARACTERISTICS OF IMPLEMENTATION MODELS OF EDUCATIONAL STRATEGIES IN FOREIGN LANGUAGE LEARNING
}

\begin{abstract}
Стаття присвячена актуальній проблемі методики навчання іноземних мов - застосуванню навчальних стратегій у процесі вивчення іноземних мов. У статті розглядаються експліцитні моделі навчання стратегій на основі інструкцій у процесі вивчення іноземної мови. Автором статті представлена порівняльна характеристика моделей навчання стратегій відомих іноземних дослідників проблеми, серед яких Р. Оксфорд, A. Чамот, Е. Кохена, М. Гренорелла і В. Харpica, Е. Макаро. Усі описані моделі навчання стратеаій передбачають напрям навчання «зверху вниз» і мають низку спільних рис, що підкреслюють важливість розвитку метакогнітивного розуміння студентами необхінності застосування навчальних стратегій, яке підкріплюється допомогою викладача. У статті представлені чотири основних кроки реалізації описаних моделей застосування навчальних стратегій у процесі вивчення іноземної мови: 1) зростання усвідомлення й розуміння студентами навчальних стратегій, які вони вже використовують у процесі вивчення іноземноі мови; 2) викладач презентує й моделює стратегії таким чином, щоб у студентів зростало усвідомлення їх власних когнітивних і навчальних процесів; 3) збільшення можливостей практикуватися задля допомоги студентам рухатися до автономного використання стратегій з поступовим зменшенням підтримки з боку викладача; 4) самооцінювання есрективності використаних стратегій і перенесення застосування їх на нові навчальні завдання в процесі вивчення іноземної мови. У процесі реалізації моделей застосування навчальних стратегій під час вивчення іноземної мови автор пропонує такі техніки й прийоми: обговорення вголос, анкетування, створення фокус-груп, постановка питань, заповнення бланків самоперевірки, ведення журналів, щоденників, портфоліо, читання спеціальної літератури щодо застосування навчальних стратегій. Ключові слова: експліцитна модель, модель навчання стратегій, навчальні стратегії на
\end{abstract}

основі інструкцій, метакогнітивні стратегії, само оцінювання.

The article deals with the current problem of the methodology of teaching foreign languages the application of learning strategies in the process of foreign languages learning. Explicit strategies learning models based on the foreign language instruction are discussed in the article. The author of the article presents comparative characteristics of strategies learning models of famous foreign researchers of the problem, among them: R. Oxford, A. Chamot, E. Cohen, M. Grenfell and V. Harris, E. Macaro. All of the described strategies learning models provide a "top-down" direction and have a number of common features that emphasize the importance of developing a metacognitive understanding of the necessity of students' use of learning strategies supported by a teacher's instruction. The article presents four main steps in implementing of the described models of application of learning strategies in the process of foreign language learning: increasing students' awareness and understanding of the learning strategies that they use in the process of foreign language learning; the teacher presents and models strategies in such way that students become aware of their own cognitive and learning processes; increasing the ability to practice that can help students move toward autonomous use of strategies with a gradual decrease in teacher support; self-assessment of the effectiveness of the strategies use and the transformation of their application to new learning tasks in the process of foreign language learning. In the process of implementation of learning strategies models in the process of foreign language learning, the author offers such techniques and tactics as: aloud discussing, questioning, creating focus groups, posing questions, filling out self-test sheets, keeping journals, diaries, portfolios, reading special literature on the application of learning strategies.

Key words: explicit model, strategy learning model, instruction-based learning strategies, metacognitive strategies, self-assessment.
Постановка проблеми в загальному вигляді. Одною з основних фоорм прояву автономії студента $€$ володіння навчальними стратегіями, вибір яких залежить від індивідуальних уподобань у способах перероблення навчальної інорормації, а також низки інших загальних й індивідуальних фракторів впливу на процес автономного навчання професійно орієнтованого англомовного спілкування. До основних цілей застосування навчальних стратегій в автономному навчанні профресійно орієнтованого англомовного спілкування відносимо такі: зробити процес навчання ефективнішим; підвищити мотивацію й упевненість у собі; формувати автономність; фрормувати самостійність; показати взаємодію стратегій вивчення іноземної мови
3 іншими дисциплінами; зробити процес навчання відкритим і зрозумілим; фрормувати відповідальність; навчити самоаналізу; навчити видозмінювати завдання.

Отже, для того щоб навчити студентів правильно застосовувати навчальні стратегії, недостатньо лише пояснити чи дати інструкцію для їх застосування. Їх необхідно тренувати. Слід використовувати завдання, які тренують не тільки застосування стратегій, але дають повну інфрормацію про саму стратегію, про її користь, про іiї застосування, а також про те, як проконтролювати еорективність використання стратегії, як застосувати певну стратегію для виконання складних завдань. 
Аналіз останніх досліджень і публікацій. Аналіз науково-педагогічних досліджень засвідчив, що серед перерахованих вище шляхів навчання стратегій найефективнішим $€$ останній спосіб - інтегрування на практичному занятті вивчення мови з вивченням мовних стратегічних інструкцій. У дослідженнях А. Чамот і М. О’Маллі [1], Р. Оксорорд і Б. Лівер [11] та інших зазначається, що в порівнянні з ізольованими (відокремленими від практичних занять) лекціями й воркшопами інтегровані в зміст дисципліни навчальні стратегії $€$ набагато ефективнішими, що уможливлює їх інкорпорацію в навчальні програми задля оптимізації навчання студентів, оскільки це передбачає застосування автентичних мовленнєвих навчальних завдань і тривалого застосування [7, с. 39].

У дослідженнях М. Гренорелла і В. Харріса [4], Р. Оксорорд [10] та інших обґрунтовується, що інструкції щодо застосування навчальних стратегій слід надавати експліцитно, інтегруючи їх у практичний курс вивчення іноземної мови, оскільки це надає можливості студентам практикувати навчальні стратегії в автентичних навчальних завданнях, а завданням викладача $€$ спрямовувати навчальний процес на досягнення навчальних цілей [6, с. 38].

Виділення не вирішених раніше частин загальної проблеми. На відміну від імпліцитного представлення стратегій, яке не забезпечує студентів спеціальним керівництвом щодо мети навчання, експліцитні інструкції культивують усвідомлене ставлення студентів до застосування стратегій, представляють стратегію, забезпечують можливості для ії практики, моделюють використання стратегії студентом, допомагають студентам в оцінці застосованої стратегії. Таким чином, вважаємо, що інорормування студентів про те, як, коли й чому використовуються стратегії, надання їм можливості застосувати стратегії в різних навчальних завданнях і перенести застосування стратегій на нові контексти й завдання під час навчання, що є надзвичайно важливим в умовах автономного навчання професійно орієнтованого англомовного спілкування.

Мета статті - провести порівняльну характеристику відомих експліцитних моделей навчання стратегій на основі інструкцій та виокремити основні кроки й прийоми їх реалізації в процесі автономного навчання професійно орієнтованого англомовного спілкування.

Виклад основного матеріалу. У науковометодичній літературі представлені різні експліцитні моделі навчання стратегій на основі інструкцій, серед яких модель П. Пірсона і Дж. Дола [12], модель Р. Оксорорд [10], модель А. Чамот [2], модель Е. Кохена [3], модель М. Гренорелла i B. Хappica [4] та інші. Розглянемо основні положення найвідоміших моделей.
Модель Ребеки Оксфорд [10] (Strategy Training Model - STM, 1990) має покрокову процедуру застосування: 1) студента просять зануритися в автентичне мовне завдання й виконати його без інструкцій і вказівок щодо навчальної стратегії 3 боку викладача; 2) викладач допомагає студентам оцінити стратегію, яку було застосовано; 3) викладач пропонує й демонструє корисні навчальні стратегії, зауваживши про необхідність більшого самокерування й зазначивши результати, що очікуються, та переконавшись, що студенти обізнані в раціональності стратегії, що використовується; 4) викладач надає студентам час, для практичного застосування нових навчальних стратегій 3 мовними чи мовленнєвими завданнями й показує, як зазначені стратегії можуть бути застосовані з іншими завданнями; 5) викладач забезпечує практику використання прийомів з новими завданнями й дозволяє студентам робити вибір щодо навчальних стратегій, які вони застосовуватимуть для виконання завдань 3 вивчення мови; 6) викладач допомагає студентам зрозуміти, як оцінити успішність їхньої навчальної стратегії й виміряти їхній прогрес, як відповідальних і самостійних студентів.

Загалом, ця модель є гнучкою з погляду процедури, іншими словами, кожен крок може бути змінений або перероблений відповідно до завдань, що мають різні потреби й наміри. Слабкою стороною моделі Р. Оксорорд є те, що ця модель важко узгоджується зі стандартною навчальною програмою вивчення іноземної мови в закладі вищої освіти.

Модель Анни Уль Чамот [2] (Cognitive Academic Language Learning Approach Model CALLA, 1988, 2005) призначена для розвитку академічних мовних навичок студентів з обмеженою іншомовною комунікативною компетентністю. Модель складається 3 шести кроків, а саме: 1) підготовка; на цьому етапі викладач визначає поточні стратегії навчання студентів для вже знайомих типів завдань, таких як активізація попередніх знань, попередній перегляд ключового словника й понять, які будуть введені на занятті; 2) презентація; викладач називає, моделює, пояснює нову стратегію, запитує студентів, чи вони колинебудь використовували іiї і як це відбувалося (наприклад, стратегія вибіркової уваги, самоконтролю, обґрунтування висновків, опрацювання, образності, конспектування тощо); 3) практика; на цьому етапі студенти практикують нову стратегію; викладач заохочує подальше використання стратегії на практиці шляхом застосування її для мовного висловлювання, планування розробки усного або письмового звіту або класифікації поняття; 4) самоконтроль; у цій фразі студенти оцінюють власну навчальну стратегію використання відразу після практики, визначаючи ефективність власного навчання шляхом підбивання підсумків або 
самостійного висловлювання, в групі або індивідуально; 5) розширення діяльності; на цьому етапі студенти переносять стратегії на нові завдання, поєднуючи стратегії в групи (кластери), розвиваючи репертуар навчальних стратегій, яким надається перевага, та інтегрують їх у межі своїх знань; 6) оцінювання; на цій стадії викладач оцінює використання студентами навчальних стратегій і їх вплив на виконання навчальних завдань.

Модель А. Чамот інтегрує навчання стратегій у змістовну (контекстну) й академічну діяльність. Модель $є$ рекурсивною (як і модель Р. Оксфорд), а не лінійною, тому викладачі й студенти завжди мають можливість переглядати попередні навчальні етапи й повертатися до них [2], і корисною для тих, хто вивчає мову на різних рівнях, що дає підстави розглядати можливість упровадження цієї моделі в умовах автономного навчання в закладі вищої освіти.

Модель М. Гренфелла і В. Харріса [4] (Modern Language and Learning Strategies Model - MLLS, 1999) поділена на п'ять частин (читання, аудіювання, запам'ятовування, перевірка письмової роботи, комунікативні стратегії) й передбачає дотримання шести кроків одного циклу, а саме: 1) усвідомлення; студенти виконують завдання без інструкцій, а потім обговорюють стратегії, які вони застосували; 2) моделювання; викладач моделює, обговорює цінність нової стратегії, робить список стратегій для подальшого застосування; 3) загальна практика; студенти практикують нові стратегії в різних завданнях; 4) планування дій; студенти ставлять індивідуальні цілі, обирають стратегії створюють власний план дій для досягнення визначених цілей; 5) фрокусування на практиці; студенти тренуються в застосуванні навчальних стратегій задля досягнення поставлених цілей в їх плані дій з поступовим зменшенням підказок і порад з боку викладача; 6) оцінювання; викладач і студенти оцінюють успішність студента під час виконання плану дій, ставлять нові цілі й процес починається знову.

Особливістю моделі Гренфелла і Харріса $€$ те, що вона є лінійною й передбачає роботу у вигляді циклу, що допомагає студентам постійно знайомитися 3 новими стратегіями й складати незалежні плани дій щодо їх власного мовного розвитку.

ще одну лінійну циклічну модель було представлено Е. Макаро [8, с. 176] (Strategy Instruction Cycle Model - SIC, 2001). Ця модель передбачає для одного циклу такі кроки: 1) активізація внутрішнього усвідомлення студентів; 2) дослідження доступних навчальних стратегій; 3) моделювання викладачем або іншими студентами; 4) комбінування стратегій для конкретної мети або завдання; 5) застосування стратегій на основі підтримки; 6) первинне оцінювання студентами; 7) поступове усунення підтримки; 8) оцінювання викладачем і студентами; 9) моніторинг застосування стратегій і винагородження зусиль.

Модель Макаро представлена у трьох варіантах, що надає можливість викладачеві обирати потрібний варіант залежно від групи студентів. Наприклад, перший варіант: навчання лише метакогнітивних, соціальних й афективних стратегій; другий варіант: навчання лише когнітивних стратегій; третій варіант: навчання одного виду мовленнєвої діяльності (читання чи письма) [9, с. 29].

Усі описані моделі навчання стратегій $€$ експліцитними й передбачають напрямок навчання «зверху вниз» (top-down) [5, с. 25]. Як зазначають дослідники, найпоширенішою й такою, що може бути взірцем моделі стратегічно орієнтованих інструкцій, є модель Анни Чамот (CALLA) [5, с. 26]. Модель стала стандартом у галузі вивчення іноземних мов, оскільки була спеціально розроблена для навчання інструкцій навчальних стратегій у процесі вивчення іноземної мови й містить інструкційний пакет матеріалів, в якому інтегровано зміст, мову й навчальні стратегії. Усім трьом компонентам навчають у п'ятирівневій послідовності (підготовка, презентація, практика, самооцінювання, розширення/перенесення) зі значним зміщенням відповідальності за навчання з викладача на студентів, завдяки чому вони стають усе більше автономними [5, с. 26]. Як зазначають дослідники Дж. Рубін, А. Чамот, В. Харріс, Н. Андерсон [13], усім моделям з напрямком «зверху вниз» притаманні чотири основних кроки: 1) зростання усвідомлення й розуміння студентами стратегій, які вони вже використовують; 2) викладач презентує й моделює стратегії таким чином, щоб у студентів зростало усвідомлення їх власних когнітивних і навчальних процесів; 3) збільшення можливостей практикуватися задля допомоги студентам рухатися до автономного використання стратегій $з$ поступовим зменшенням підтримки з боку викладача; 4) самооцінювання ефективності використаних стратегій і перенесення застосування їх на нові навчальні завдання.

Задля реалізації зазначених кроків дослідники пропонують використовувати такі техніки й прийоми, як обговорення вголос, анкетування, створення фрокус-груп, постановка запитань, заповнення бланків самоперевірки, ведення журналів, щоденників, портфоліо, читання спеціальної літератури щодо застосування навчальних стратегій.

Висновки. Таким чином, всі вищезгадані моделі мають низку спільних рис, що підкреслюють важливість розвитку метакогнітивного розуміння студентами важливості застосування навчальних стратегій, яке підкріплюється допомогою викладача. Репертуар стратегій опанування іноземної мови формується кожним студентом індивідуально й може залишатися незмінним або розширюватися завдяки опануванню нових стратегій. 


\section{БІБЛІОГРАФІЧНИЙ СПИСОК:}

1. Chamot A.U., O'Malley J.M. The cognitive academic language learning approach: A bridge to the mainstream. TESOL Quarterly. 1987. № 21. P. 227-249.

2. Chamot A.U. The Cognitive Academic Language Learning Approach (CALLA): An update. In P.A. Richard-Amato \& M.A. Snow (Eds.), Academic success for English language learners: Strategies for K-12 mainstream teachers. White Plains, NY : Longman. P. 87-101.

3. Cohen A.D. Strategies in Learning and Using a Second Language. Addison Wesley Longman Limited. 1998, 2000.

4. Grenfell M., Harris V. Modern languages and learning strategies: In theory and practice. London: Routledge. 1999.

5. Gu P.Y. Approaches to Learning Strategy Instruction. Learning Strategy Instruction in the Language Classroom. Issues and Implementation I Edited by A.U. Chamot, V. Harris. 2019. P. 22-37.

6. Jarupan, Sarada. The Use of "5A Learning Portfolio", a Technique of Learning Strategies Based on Self-Directed Learning and Metacognition to Enhance English Learning Skills of Thai Engineering Students. PSAKU International Journal of Interdisciplinary Research. 2019. Vol. 8 №. 1, P. 35-47.
7. Lai Ying-Chun. Integrating vocabulary learning strategy instruction into efl classrooms. Taiwan Journal of TESOL. 2013. Vol. 10.1, P. 37-76.

8. Macaro E. Learning strategies in foreign and second language classrooms. London: Continuum. 2001.

9. Manan N. The Effects of Language Learning Strategy (LLS) Training on ESL College Students' Strategies Used. Gading Business and Management Journal. 2011. Vol .15. P. 25-40.

10. Oxford R. Language Learning Strategies: What Every Teacher Should Know. Rowley, Mass : Newbury House. 1990. P. 284-297.

11. Oxford R.L., Leaver B.L. A synthesis of strategy instruction for language learners. In R.L. Oxford (Ed.) Language learning strategies around the world: Crosscultural perspectives. Honolulu, $\mathrm{HI}$ : University of Hawaii Press. 1996. P. 227-246.

12. Person P.D., Dole J.A. Explicit Comprehension Instruction: A Review of Research and a New Conceptualization of Learning. Elementary School Journal. 1987. Vol.88. № 2, P. 155-165.

13. Rubin J. etc. Intervening in the use jf strategies. Language Learner Strategies: Thirty Years of Research and Practice / in A. Cohen and E. Macaro. 2007. Oxford : Oxford University Press. P. 141-160. 